\title{
Assistance and educational factors associated to congenital syphilis in a referral maternity: a case-control study
}

Felipe Leonardo Rigo 1

iD https://orcid.org/0000-0002-4726-1617

Roberta Maia de Castro Romanelli 2

iD https://orcid.org/0000-0002-1660-0751

lara Paiva Oliveira 3

(iD https://orcid.org/0000-0003-0619-4398

Lêni Marcia Anchieta 4

(iD) https://orcid.org/0000-0002-3336-9504

\begin{abstract}
1 Programa de Pós-Graduação em Ciências da Saúde. Saúde da Criança e do Adolescente. Faculdade de Medicina. Universidade Federal de Minas Gerais. Belo Horizonte, MG, Brasil.

2,3,4 Departamento de Pediatria. Faculdade de Medicina. Universidade Federal de Minas Gerais. Av. Alfredo Balena, 190, sala 533. CEP: 31.270-901. Belo Horizonte, MG, Brasil. E-mail: lenimaa@gmail.com
\end{abstract}

\begin{abstract}
Objectives: to investigate the information received by pregnant women considering assistance care and educational factors on syphilis and its association with the diagnostic of congenital syphilis in a referral maternity.

Methods: a case-control study conducted in a referral maternity in Minas Gerais, Brazil, from 2017 to 2018. A case group included newborns' mothers with presumptive congenital syphilis and A control group was considered healthy newborns' mothers. Clinical, obstetrics variables and information about maternal educational approach on syphilis during prenatal care were obtained through interviews and medical records. Descriptive and comparative analyses were performed. Chi-square or Fisher's exact test and odds ratio were calculated followed by multivariate logistic regression.

Results: sixty mothers were included in the case group and 120 mothers in the control group. Mothers in the case group presented lower schooling level and they were 24 times more likely to have information about the risks of congenital syphilis and five times more likely to had received previous treatment for syphilis and mothers in the control group were 10 times more likely to receive information about Sexually Transmitted Infections during prenatal care.

Conclusion: adequate health assistance identifying previous history of syphilis and health education improving its information about Sexually Transmitted Infections can help prevent congenital syphilis, which indicates the necessity of a better approach by the professionals during prenatal care.
\end{abstract}

Key words Syphilis, Congenital syphilis, Women's health, Health education

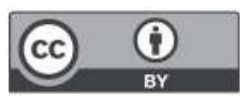




\section{Introduction}

According to the World Health Organization (WHO), it is estimated that syphilis affects about one million women, and there are over 600 cases of congenital syphilis annually, with 4.7 cases/1,000 live births and more than 300,000 cases associated to fetal or neonatal deaths and prematurity. ${ }^{1}$ The increase in acquired syphilis cases in the general population, in pregnant women and in the congenital form, in several countries, shows the reemergence of the disease. ${ }^{1-3}$ In Brazil, it is also observed that the reported numbers of cases in pregnant women represent half of the number of cases of congenital syphilis, a fact that may be associated with the failure of prenatal care for these women. ${ }^{3}$ The higher number of cases may represent the increase of rapid test coverage, notifications and technical improvement of the surveillance system, but it is also due to reduced practices as condom use; non-administration of penicillin in primary care, as it is recommended; and drug shortage in the pharmaceutical market.1,3,4

Government strategies in improving epidemiological surveillance, prenatal care quality focusing on the diagnosis, and treatment of the disease in Basic Health Units, 5,6 besides professional education and technical training, are fundamental to prevent, control and cure Sexually Transmitted Infections (STIs).4,7 For epidemic control, the Agenda of Strategic Actions for Syphilis Reduction in Brazil has been working since 2017,8 and the Rapid Response to Syphilis Project in Health Care Networks ${ }^{9}$ started in 2018.

The association of maternal demographic characteristics or prenatal assistance and the occurrence of congenital syphilis have been shown in literature. 10-16 The scarcity of studies that focus on health professional education as a factor associated with the prevention of congenital syphilis motivated the hypothesis besides clinical variables, the information in health education received during prenatal care can be associated to the cases of congenital syphilis. This study aims to investigate the information received about educational practices and the assistance care on syphilis during prenatal care and its association with the diagnosis of congenital syphilis, from the pregnant women's point of view.

\section{Methods}

This case-control study was conducted between September 2017 and September 2018, in a reference maternity hospital in Belo Horizonte.

All the women who went into labor during the study period at the maternity were taken into consideration in being included, if the presumptive diagnosis of congenital syphilis were considered. The case group population was consisted of newborns' mothers with the presumptive diagnosis of congenital syphilis, identified through a daily pharmacy dispensing report on penicillin for the newborns and the confirmation of the diagnosis in the newborn's medical record.

For the control group sample, newborns' mothers with good clinical evolution in the immediate neonatal period and were born in the same week of birth when the case group were identified was to avoid temporal modifications in the assistance or the hospital routines. No other variables were used to pair cases and control of newborns or mothers. From the identification of the case, an active search in the birth records was performed to identify the control group healthy newborns' mothers.

Data were obtained through directed interviews at postpartum and data collection were from registered medical records in structured questionnaire form. The identification of case and control groups, all the interviews and data collection were performed by one of the researchers, who was also responsible for the health assistance and knows the maternity routine. The researcher approached the women after labor when they were clinically stable, and was responsible in explaining the study and applying the Informed Consent Term.

The independent variables were classified into clinical assistance and educational information received during prenatal care. The assistance variables included: sociodemographic characteristics (age, ethnicity, marital status, schooling, family income rate); obstetric history (previous pregnancies, abortion, preterm birth, syphilis treatment, partner's syphilis treatment, contraceptive method use); current pregnancy prenatal healthcare, and neonatal characteristics (prenatal follow-up, early prenatal insertion, presence of comorbidities, newborn's sex, gestational age at birth, birth weight, weight versus gestational age, manifestations of congenital syphilis). Educational variables included: a) receive information on syphilis transmission and other STIs, during prenatal care (screening, diagnosis, transmission, treatment, partner's treatment, risk to woman, risk to fetus/newborn); understand this information; identify the professional responsible for the information; b) Approach on the diagnosis of syphilis in the current pregnancy; time of diagnosis (during prenatal care or at the maternity); exams performed and the registration of presence on their prenatal card; information about test results, 
diagnosis, treatment; support and partner's treatment; professional responsible for this; educational approach and methodology.

For the sample calculation, the prevalence of congenital syphilis of $4 \%$ and approximately 11,000 parturient/year was taken in consideration, with a $95 \%$ confidence interval and 5\% accuracy in identifying at least an OR of 5, a minimum of 24 cases for the case groups. The sample for the control groups was concomitantly included at a 1:2 ratio, considering a heterogeneous sample.

Statistical analyses were performed by using the Statistical Package for Social Sciences ${ }^{\circledR}$ software (SPSS, Chicago, IL, USA, version 18.0 for Windows). In the descriptive analysis, continuous variables were presented as mean, and standard deviation or median. As for categorical variables, its frequency and proportion were calculated. Continuous variables were transformed into dichotomous for test comparison between the groups and Pearson Chi-square test or Fisher's exact test was considered. The estimated measure association was the Odds ratio with $95 \%$ Confidence Interval. For multivariate analysis, all significant variables were included and binary logistic regression was performed. The models were adjusted and statistical significance in the final model variables were considered when $p \leq 0.05$.

Research Ethics Committees from the Universidade Federal de Minas Gerais and the Hospital Sofia Feldman approved the study (67845517.7.3001.5149 and CAAE 67845517.7.3001.5132) on July 28, 2017 and on August 2, 2017. The Informed Consent Term was solicitated to all participants.

\section{Results}

A total of 180 postpartum women: 60 newborns' mothers with presumptive diagnosis of congenital syphilis (case group), and 120 newborns' mothers without diagnosis of syphilis (control group) were interviewed. No invited women refused to consent and to participate in the study.

It is important to emphasize that Venereal Disease Research Laboratory (VDRL) was performed in 58 (96.7\%) women and Fluorescent Treponemal Antibody Absorption (FTABS) was requested in only $2(3.3 \%)$ of them. The complete registration of these exams was found, $61.7 \%$, at the prenatal care.

Table 1 presents sociodemographic data, with a predominance of women ranging from 20 to 29 years of age. Family income was of 1 to 2 minimum wages in the case and control groups with no statistical difference. Non-white $(p=0.028)$, single $(p=0.003)$ and illiterate or incomplete elementary schooling $(p<0.001)$ were significantly more frequent in the case group.

Obstetric history and current pregnancy are shown in Table 2, which highlights that being multiparous $(p<0.001)$, already underwent syphilis treatment $(p<0.001)$, starting prenatal care in the first trimester of pregnancy $(p=0.011)$, and had comorbidities $(p=0.005)$ and preterm birth $(p=0.011)$ were significantly more frequent in the case group. Regarding the contraceptive method, although, it was not statistically significant, but was observed a low frequency of condom use in both groups $(n=2$ and $n=3$, in case and control groups, respectively). The method more frequently reported was hormonal contraception. Women with comorbidities were identified only in the case group $(p<0.001)$.

Table 3 presents the data of on educational approach for pregnant women and parturients, according to their perception. In the univariate analysis, information about disease transmission $(p<0.001)$ and syphilis risk to women and fetus/newborn $(p<0.001)$ were significantly more frequent in the case group. Information about STIs was significantly more frequent in the control group $(p<0.001)$. Physicians were professionals more frequently responsible for the information, although, there were no statistical difference in any of these variables. Information occurred exclusively by verbal exposure.

To avoid possible interference of the variables with the same socio-demographic profile, assistance care and associated responses in the interview, multivariate analysis was performed to identify variables with independent association with the outcome. In the multivariate logistic regression, the following variables remained significant for the case group: low schooling level (Illiterate/Incomplete elementary schooling $-\mathrm{OR}=5.50$ CI95\% $=1.79-16.95)$, previous syphilis treatment $(\mathrm{OR}=5.73$; CI95\% $=1.40$ $23.90)$ and the information about syphilis risks to the fetus/newborn $(\mathrm{OR}=20.17$; CI95\%=6.52-62.44). As for the control group, information on other STIs during prenatal care was significantly more frequent $(\mathrm{OR}=6.80 ; \mathrm{CI} 95 \%=1.92-24.39)$, with a prediction of $83.7 \%$ by the model (Table 4 ). Hosmer-Lemeshow test showed adequate adjustment model $(p=0.71)$.

Thus, it was observed that women with lower schooling level were five times more likely to have newborns with congenital syphilis. Those women with history of previous syphilis were five times more likely to have newborns with congenital 
Comparison on sociodemographic variables between women with newborns with presumptive syphilis (case) and women with healthly newborns (control) at Hospital Sofia Feldman, Belo Horizonte- MG, 2018.

\begin{tabular}{|c|c|c|c|c|c|c|}
\hline $\begin{array}{l}\text { Variables } \\
\text { Age (years) }\end{array}$ & \multicolumn{2}{|c|}{$\begin{array}{c}\text { Case } \\
(\mathrm{N}=60)\end{array}$} & \multicolumn{2}{|c|}{$\begin{array}{l}\text { Control } \\
(N=120)\end{array}$} & OR (Cl95\%) & $p$ \\
\hline$<20$ & 14 & 23.3 & 22 & 18.3 & $0.71(0.28-1.78)$ & \\
\hline $20-29$ & 32 & 53.3 & 67 & 55.8 & $0.95(0.44-2.02)$ & \\
\hline$\geq 30$ & 14 & 23.3 & 31 & 25.8 & - & \\
\hline Etnicity (self-declared) & & & & & & $0.028^{b}$ \\
\hline White & 4 & 6.7 & 23 & 19.2 & $3.32(1.09-10.09)$ & \\
\hline Non-white & 56 & 93.3 & 97 & 8.8 & & \\
\hline Marital status & & & & & & $0.003 b$ \\
\hline Single or divorced & 31 & 51.7 & 40 & 33.3 & $0.704(0.355-1.39)$ & \\
\hline Married & 5 & 8.3 & 36 & 30.0 & $3.927(1.36-11.33)$ & \\
\hline Stable union & 24 & 40.0 & 44 & 36.7 & & \\
\hline Schooling & & & & & & $<0.001 a$ \\
\hline Illiterate / Incomplete elementary school & 23 & 38.3 & 10 & 8.3 & $0.102(0.04-0.25)$ & \\
\hline \multicolumn{7}{|l|}{ Complete elementary school/ } \\
\hline Incomplete high school & 19 & 31.7 & 33 & 27.5 & $0.406(0.19-0.87)$ & \\
\hline \multicolumn{7}{|l|}{ Complete high school / Higher education / } \\
\hline Post -graduation & 18 & 30.0 & 17 & 64.2 & & \\
\hline Family income*(minimum salary) & & & & & & $0.184 a$ \\
\hline$<1$ & 12 & 20.0 & 15 & 12.5 & $0.375(0.13-1.09)$ & \\
\hline $1-2$ & 39 & 65.0 & 75 & 62.5 & $0.577(0.25-1.34)$ & \\
\hline$\geq 30$ salaries & 9 & 15.0 & 30 & 25.0 & - & \\
\hline
\end{tabular}

a Pearson $\chi^{2}$; b Fisher exact test.

syphilis, and 20 times more likely to receive information about risks of transmitting the disease to the newborn. Women in the control group were six times more likely to receive information about other STIs during prenatal care.

\section{Discussion}

In the case group, despite high prenatal coverage (96.7\%), the diagnosis of syphilis in the maternity hospital represented $36.7 \%$ of the cases, which shows a possible gap in prenatal care, since the timely identification of syphilis is critical for the treatment and the reduction of congenital syphilis. Prenatal screening for syphilis (first visit; 28 weeks and childbirth) is recommended, in order to identify possible infection during pregnancy.1,2,3 Despite the high screening coverage (63.3\%), the present study was not design to study and did not evaluate the adequacy of the screening frequency.

A United Nations Organization publication about prenatal coverage (147 countries) and syphilis screening (76 countries) reports that $66 \%$ of syphilis-related adverse events such as fetal mortality, stillbirth and neonatal death were identified in concepts of women not being tested during prenatal care. ${ }^{17}$ A Brazilian population survey (more than 36,000 pregnant women) presented an association between syphilis diagnosis and absence of prenatal care, late prenatal onset, less than 6 consultations, or no information about prenatal care. 10 In a historical cohort about prenatal care in the Basic Health Units in Belo Horizonte, the same city of the present study, was observed that VDRL was performed late in prenatal care by $56.6 \%$ of the pregnant women, and $7.1 \%$ had negative VDRL in the first screening. 15

Although it is recommended that a treponemal test be performed after positive screening with a non-treponemal test, 1 the percentage of this test in this study was low (3.3\%). However, treatment is not dependent of these results. ${ }^{1,6-9}$ Registration on the prenatal card is essential to improve prenatal assistance, since it provides information about prenatal care. 18 In an epidemiological study, in another Brazilian capital, Vitória, a metropolitan region, was observed that only $35 \%$ of the cases had syphilis screening registered in the prenatal card. 19 
Comparison of variables of obstetric history, current pregnancy and neonatal characteristics between women with newborns with presumptive syphilis (case) and women with healthly newborns (control) Hospital Sofia Feldman, Belo Horizonte-MG, 2018.

\begin{tabular}{|c|c|c|c|c|c|c|}
\hline $\begin{array}{l}\text { Variables } \\
\text { Obstetric history }\end{array}$ & \multicolumn{2}{|c|}{$\begin{array}{c}\text { Case } \\
(\mathrm{N}=60)\end{array}$} & \multicolumn{2}{|c|}{$\begin{array}{r}\text { Control } \\
(\mathrm{N}=120)\end{array}$} & OR (Cl95\%) & $p$ \\
\hline Multiparous & & & & & & $0.001^{a}$ \\
\hline Yes & 43 & 71.7 & 56 & 46.7 & - & \\
\hline No & 17 & 28.3 & 64 & 53.3 & $2.891(1.49-5.63)$ & \\
\hline Abortion & & & & & & $0.209 a$ \\
\hline Yes & 8 & 18.6 & 6 & 10.0 & - & \\
\hline No & 35 & 81.4 & 54 & 90.0 & $2.057(0.66-6.44)$ & \\
\hline Prematurity & & & & & & $0.66 \mathrm{~b}$ \\
\hline Yes & 4 & 9.3 & 4 & 6.9 & - & \\
\hline No & 39 & 90.7 & 54 & 93.1 & $1.39(0.33-5.88)$ & \\
\hline Previous syphilis treatment & & & & & & $<0.001 \mathrm{~b}$ \\
\hline Yes & 17 & 28.3 & 4 & 3.3 & - & \\
\hline No & 43 & 71.7 & 116 & 96.7 & $11.465(3.652-35.993)$ & \\
\hline Partner's treatment & & & & & & $0.016 \mathrm{~b}$ \\
\hline Yes & 5 & 8.3 & 1 & 0.8 & - & \\
\hline No & 55 & 91.7 & 119 & 99.2 & $1.25(0.10-15.11)$ & \\
\hline Contraceptive method & & & & & - & $0.460 \mathrm{a}$ \\
\hline Yes & 29 & 48.3 & 65 & 54.2 & - & \\
\hline No & 31 & 51.7 & 55 & 45.8 & $0.79(0.43-1.47)$ & \\
\hline \multicolumn{7}{|l|}{ Current pregnancy } \\
\hline Prenatal & & & & & & $0.110 \mathrm{~b}$ \\
\hline Yes & 58 & 96.7 & 120 & 100.0 & - & \\
\hline No & 2 & 3.3 & 0 & - & $3.07(2.48-3.79)$ & \\
\hline First prenatal consultation & & & & & & $0.007 \mathrm{~b}$ \\
\hline 1st trimester & 41 & 70.7 & 106 & 88.3 & - & \\
\hline 2nd trimester & 15 & 25.9 & 12 & 10.0 & $2.59(0.35-18.97)$ & \\
\hline 3rd trimester & 2 & 3.4 & 2 & 1.7 & $0.80(0.98-6.55)$ & \\
\hline Comorbidades & & & & & & $<0.001 b$ \\
\hline Yes (Diabetes Mellitus; Hypertension) & 8 & 13.6 & 0 & - & - & \\
\hline No & 51 & 86.4 & 120 & 100.0 & $0.30(0.24-0.38)$ & \\
\hline Newborn & & & & & & $0.073^{a}$ \\
\hline Female & 37 & 61.7 & 57 & 47.5 & $0.56(0.30-1.06)$ & \\
\hline Male & 23 & 38.3 & 63 & 52.5 & - & \\
\hline Preterm & & & & & & $0.004 b$ \\
\hline Yes & 9 & 15.0 & 4 & 3.3 & $0.20(0.06-0.66)$ & \\
\hline No & 51 & 85.0 & 116 & 96.7 & - & \\
\hline Low birth weight and Very low birth weight & & & & & & $0.040^{a}$ \\
\hline Yes & 12 & 20.0 & 11 & 9.2 & - & \\
\hline No & 48 & 80.0 & 109 & 90.8 & $2.48(1.02-6.01)$ & \\
\hline Small for gestational age & & & & & & $0.325 \mathrm{a}$ \\
\hline Yes & 9 & 15.0 & 12 & 10.0 & - & \\
\hline No & 51 & 85.0 & 108 & 90.0 & $0.63(0.25-1.59)$ & \\
\hline
\end{tabular}

a Pearson $\chi^{2}$; b Fisher exact test. 
Comparison of educational information variables on syphilis and other Sexually Transmitted Infections during prenatal between women with newborns with presumptive syphilis (case) and women with healthly newborns (control). Hospital Sofia Feldman, Belo Horizonte-MG, 2018.

\begin{tabular}{|c|c|c|c|c|c|c|}
\hline $\begin{array}{l}\text { Variables } \\
\text { Screening for syphilis }\end{array}$ & \multicolumn{2}{|c|}{$\begin{array}{c}\text { Case } \\
(\mathrm{N}=60)\end{array}$} & \multicolumn{2}{|c|}{$\begin{array}{l}\text { Control } \\
(\mathrm{N}=120)\end{array}$} & OR (Cl95\%) & $p$ \\
\hline Information about screening & & & & & & $0.351 \mathrm{a}$ \\
\hline Yes & 51 & 87.9 & 99 & 82.5 & $1.55(0.62-3.88)$ & \\
\hline No & 7 & 12.1 & 21 & 17.5 & - & \\
\hline Clear and objective information & & & & & & $0.847 a$ \\
\hline Yes & 26 & 51.0 & 55 & 55.6 & $1.25(0.58-2.72)$ & \\
\hline No & 9 & 17.6 & 17 & 17.2 & $1.12(0.41-3.10)$ & \\
\hline Partially & 16 & 31.4 & 27 & 27.3 & - & \\
\hline Professional responsible for the information & & & & & & $0.489 a$ \\
\hline Physician & 27 & 52.9 & 55 & 55.6 & $1.34(0.64-2.80)$ & \\
\hline Nurse & 5 & 9.8 & 15 & 15.2 & $1.97(0.61-6.31)$ & \\
\hline Both & 19 & 37.3 & 55 & 55.6 & - & \\
\hline \multicolumn{7}{|l|}{ Syphilis } \\
\hline Information about syphilis transmission & & & & & & $<0.001 \mathrm{a}$ \\
\hline Yes & 28 & 48.3 & 17 & 14.2 & $0.18(0.09-0.37)$ & \\
\hline No & 30 & 51.7 & 103 & 85.8 & - & \\
\hline Clear and objective information & & & & & & $0.259 \mathrm{~b}$ \\
\hline Yes & 20 & 71.4 & 16 & 94.1 & $4.8(0.52-44.05)$ & \\
\hline No & 2 & 7.1 & 0 & - & - & \\
\hline Partially & 6 & 21.4 & 1 & 5.9 & - & \\
\hline Professional responsible for the information & & & & & & $0.450 \mathrm{~b}$ \\
\hline Physician & 17 & 60.7 & 8 & 47.1 & $0.71(0.19-2.67)$ & \\
\hline Nurse & 2 & 7.1 & 3 & 17.6 & $2.25(0.29-17.76)$ & \\
\hline Both & 9 & 32.1 & 6 & 35.3 & - & \\
\hline \multicolumn{7}{|l|}{ Risk of syphilis to the women } \\
\hline Information about syphilis risk & & & & & & $<0.001 \mathrm{a}$ \\
\hline Yes & 28.0 & 48.3 & 7 & 5.8 & $15.07(5.99-37.84)$ & \\
\hline No & 30.0 & 51.7 & 117 & 94.2 & - & \\
\hline Clear and objective information & & & & & $2.40(0.25-23.24)$ & $0.648 \mathrm{~b}$ \\
\hline Yes & 20 & 71.4 & 6 & 85.7 & & \\
\hline No & 0 & - & 0 & - & & \\
\hline Partially & 8 & 26.8 & 1 & 14.3 & & \\
\hline Professional responsible for the information & & & & & & $0.207 \mathrm{~b}$ \\
\hline Physician & 16 & 57.1 & 4 & 57.1 & $2.50(0.24-25.68)$ & \\
\hline Nurse & 2 & 7.1 & 2 & 28.6 & $10.00(0.58-171.20$ & \\
\hline Both & 10 & 35.7 & 1 & 14.3 & - & \\
\hline \multicolumn{7}{|l|}{ Risk of syphilis to fetus/newborn } \\
\hline Information about syphilis risk & & & & & & $<0.001 \mathrm{a}$ \\
\hline Yes & 29 & 50.0 & 5 & 4.2 & $23.00(8.19-64.60)$ & \\
\hline No & 29 & 50.0 & 115 & 95.8 & - & \\
\hline Clear and objective information & & & & & & $1.000 \mathrm{~b}$ \\
\hline Yes & 20 & 69.0 & 4 & 80.0 & $1.600(0.15-16.61)$ & \\
\hline No & 1 & 3.4 & 0 & - & - & \\
\hline Partially & 8 & 27.6 & 1 & 20.0 & & \\
\hline Professional responsible for the information & & & & & & $0.570 \mathrm{~b}$ \\
\hline Physician & 18 & 62.1 & 3 & 60.0 & $1.50(0.14-16.54)$ & \\
\hline Nurse & 2 & 6.9 & 1 & 20.0 & $4.50(0.19-106.82)$ & \\
\hline Both & 9 & 31.0 & 1 & 20.0 & - & \\
\hline
\end{tabular}


Comparison of educational information variables on syphilis and other Sexually Transmitted Infections during prenatal between women with newborns with presumptive syphilis (case) and women with healthly newborns (control). Hospital Sofia Feldman, Belo Horizonte-MG, 2018.

\begin{tabular}{|c|c|c|c|c|c|c|}
\hline \multirow{2}{*}{$\begin{array}{l}\text { Variables } \\
\text { Information about other STIS }\end{array}$} & \multicolumn{2}{|r|}{$\begin{array}{c}\text { Case } \\
(\mathrm{N}=60)\end{array}$} & \multicolumn{2}{|c|}{$\begin{array}{l}\text { Control } \\
(\mathrm{N}=120)\end{array}$} & \multirow[t]{2}{*}{ OR (CI95\%) } & \multirow[t]{2}{*}{$p$} \\
\hline & & & & & & \\
\hline Information about STIs transmission & & & & & & $<0.001 \mathrm{a}$ \\
\hline Yes & 46 & 79.3 & 115 & 95.8 & - & \\
\hline No & 12 & 20.7 & 5 & 4.2 & $0.17(0.56-0.50)$ & \\
\hline Clear and objective information & & & & & - & $0.449 b$ \\
\hline Yes & 26 & 56.5 & 77 & 67.0 & $1.57(0.76-3.23)$ & \\
\hline No & 2 & 4.3 & 4 & 3.5 & $1.06(0.18-6.35)$ & \\
\hline Partially & 18 & 39.1 & 34 & 29.6 & - & \\
\hline Professional responsible for the information & & & & & & $0.151 \mathrm{~b}$ \\
\hline Physician & 25 & 54.3 & 61 & 53.0 & $1.29(0.62-2.70)$ & \\
\hline Nurse & 3 & 6.5 & 20 & 17.4 & $3.53(0.92-13.50)$ & \\
\hline Both & 18 & 39.1 & 34 & 29.6 & - & \\
\hline
\end{tabular}

a Pearson $\chi^{2}$; b Fisher exact test; STIs= Sexually Transmitted Infections.

Table 4

Multivariate analysis for maternal data and information associated to the outcome of cases of presumptive congenital syphilis. Hospital Sofia Feldman, Belo Horizonte-MG, 2018.

\begin{tabular}{lcccc}
\hline Variable & Coefficient & p & OR & CI95\% \\
\hline Schooling (1 - Illiterate / Incomplete elementary school) & 1.70 & 0.003 & 5.50 & $1.79-16.95$ \\
History of previous syphilis treatment (1-Yes) & 1.75 & $<0.001$ & 5.73 & $1.40-23.90$ \\
Approach on syphilis risk for the newborn (1-Yes) & 3.00 & $<0.001$ & 20.17 & $6.52-62.44$ \\
Approach about other sexually transmitted infections & & & 6.003 & $1.92-24.39$ \\
$\quad(1-$ No) & & & & \\
\end{tabular}

In relation to the educational approach, it was observed that $29.6 \%$ of the parturients reported that they did not receive any information about the screening and diagnosis of syphilis. This was also demonstrated in a qualitative study carried out in a Brazilian health center specialized in STIs (Bauru/SP), in which participants reported that they had little previous knowledge about syphilis, or were unaware of the disease, a factor that may favor greater chances of transmission and absence of treatment. 20 In the present study, women who received information reported that it was exclusively through verbal exposure. In an educational and health study on syphilis conducted for pregnant women in Sobral (Ceará), 21 the educational activities were reported by the participants as responsible for increasing the knowledge about congenital syphilis and raising the awareness about prevention and treatment. In a study conducted in Paraná,22 it was also observed that there was a reduction of $38 \%$ in vertical transmission of syphilis after training professionals for primary care level, according to the recommendations of the national program to assist pregnant women. Thus, it is considered that the information is important to adherence in preventing measures and activities for health education activities by improving the comprehension of the information received.

Considering the follow up on gestational syphilis treatment, $41.7 \%$ of the women in this study performed VDRL after the treatment, which may be underestimated by the percentage of diagnosis performed at the maternity, without a follow up after discharge. Monitoring VDRL titles is fundamental to classify adequacy of the treatment. 1,7 Regarding to 
the partner's treatment, it was performed in few cases $(28.3 \%)$. A multicenter descriptive study conducted at a public maternity in the Federal District, found that treatment was not performed in $16.4 \%$ of the pregnant women with syphilis, and the partner's treatment was considered inappropriate, or merely not performed in $88.1 \%$ of the cases. $23 \mathrm{~A}$ retrospective cohort of congenital syphilis cases (Belo Horizonte/MG) revealed that one of the main reasons to consider maternal treatment inappropriate was the inadequate partner treatment in $77.4 \%$ of the cases. 24 Non-treatment or inadequate treatment for the men entails risks for congenital syphilis, as the history of sexual partners and the partner's treatment should be considered to define appropriate treatment for the pregnant women and to control congenital syphilis. $1,4,11$ A Brazilian study revealed that $64.07 \%$ of the partners are not adequately approached, they have negative serology and are not present in the consultations. 13

Most of the women diagnosed with syphilis were between 20 and 39 years old, in reproductive age, considering also, other studies investigating syphilis in pregnant and other women. 13,25 This age group also presents increased sexual activity, multiple partners and non-adherence to preventive measures, as condom use, being more vulnerable to syphilis and other STIs.7,25 In another case-control study, Macedo et al.16 identified risk factors for syphilis in pregnant women as: more than two sexual partners, first pregnancy under 18 years of age, and more than two pregnancies $(p<0.001)$. On the other hand, there was no difference in the report on condom use. In the present study, there was no statistical difference for age group, but multiparity was significant higher for the case group in univariate analysis.

Regarding ethnicity, most women in both groups self-declared being mixed skin color, according to other Brazilian studies investigating syphilis in pregnancy. $10,14,15$ However, the association of ethnicity and syphilis in a country where there is miscegenation as Brazil, is difficult to consider.

Being single or divorced and having low schooling level were features associated with a higher risk of congenital syphilis in univariate analysis. Being single may be also associated to vulnerable behaviors, non-adherence to condom use and multiple exposure to sexual partnerships.16,24 Another case-control study, conducted in Minas Gerais, with a smaller number of patients did not observe any statistical difference regarding marital status, although most women were single.14 The association with low schooling level was also demonstrated by other authors in similar national studies. 10,13,15,16 However, literature also presents low income rate and low socioeconomic status as a factor associated with syphilis. 2,4,11 Considering demographic variables in this study, only low schooling level remained associated to women with newborns with congenital syphilis as an independent factor in multivariate analysis. This variable is associated with the women's profile assisted at public health services and lower schooling level can be also associated with the comprehension of information in health assistance, which also indicates the necessity of better health educational activities involving these women for better involvement in syphilis and other STIs prevention practices.

Considering obstetric history, the present study showed that the previous history of syphilis treatment in pregnant women remained significantly more frequent in the case group in multivariate analysis, with more than 5 times higher chances. The case-control study by Macedo et al., 16 which investigated 561 pregnant women, screened with VDRL, revealed 9.7 times greater chances of previous STIs in the case group, in multivariate analysis, indicating the possibility of reinfection. To prevent infection or reinfection, it is necessary to reflect on possible assistance failures for women, and in the partners' approach to concomitant treatment during prenatal.1,3,26 Previous history of syphilis must always be investigated, once reinfection should be considered even with low titles of non-treponemal tests and adequate treatment is mandatory to prevent cases of congenital syphilis. 1,7

It is noteworthy that the use of barrier contraception is the most effective way to prevent the transmission of syphilis and other STIs. $1,4,7$ In the present study, frequency of condom use was very low in both groups and there was no statistical difference. These data are corroborated by another case-control study carried out in Brazil.16

In current pregnancy evaluated in this study, there was high adherence to prenatal care, with no difference between groups; but the insertion in prenatal care in the first trimester of pregnancy was lower in the case group. Early prenatal care and timely approach of pregnant women increase the chances of treatment and decrease the risk of congenital syphilis. 1,4 Data from the Ministry of Health ${ }^{3}$ show that only $31.6 \%$ of the pregnant women with syphilis initiate prenatal care in the first trimester, revealing the necessity of actions for early insertion, screening and treatment for these women.

Adverse neonatal characteristics, such as prematurity, low weight and death are related to congenital syphilis. 17,27 In the present study, the rates of prema- 
turity and small newborns for gestational age were higher in the case group, but significant differences were observed only in univariate analysis. Data from several countries, in a recent WHO publication, 28 revealed that the occurrence of congenital syphilisrelated adverse events continues worldwide, with a decrease in Africa, but an increase in the Americas and in the Eastern Mediterranean. These outcomes were identified in $57 \%$ of newborns' mothers not screened; $21 \%$ of newborns' mothers were without prenatal care; $16 \%$ of newborns' mothers were diagnosed with syphilis without treatment; and $6 \%$ of newborns' mothers were treated, which reveals a continuing need for improvement in prenatal care. 28

In the univariate analysis of educational factors related to information about syphilis during prenatal care, it was observed that the information about syphilis, risk of the disease for women and for the fetus/newborn were significantly higher in the case group. Information about other STIs was significantly higher in the control group. The information was considered clear and objective for most women, without differences between groups, and the medical professional was primarily responsible for this. The low percentage of counseling by nurses should be emphasized, since they perform prenatal consultations in primary care and are responsible for developing educational activities, such as prevention of syphilis and other STIs. 29,30

As an independent factor in multivariate analysis, information regarding risks to the fetus/newborn remained significantly associated with mothers in the case group, who were 20 times more likely to have been counseled. Probably, health professionals act mainly when there is a potential risk or when the disease is already present. Information about other STIs also remained significantly more frequently in the control group, presenting more than 6 times greater chances of uninfected women being informed about the transmission of these diseases. This reveals the importance of health professionals acting with this focus on the prevention of STIs and their associated complications as recommended by the National Guidelines.7

This study has limitations, such as the use of direct interview for analysis and interpretation of data about maternal syphilis, once there is a possibility of omitting information regarding the risk behavior concerning syphilis and other STIs.
Besides, the study was performed to have an internal validity, but an external validity can be considered once it was performed in one of the most important referral public maternity in the Metropolitan Region in Belo Horizonte, which represents the profile of assisted pregnant women and their newborns. In addition, this study considered a description of presumptive syphilis in newborns who started the treatment. This is recommended, based on screening, history of maternal treatment and initial propaedeutics of the newborn; but the diagnostic confirmation by treponemal tests is recommended at 18 months of age. 1

In conclusion, this study demonstrated the importance to improve the approach on pregnant women including information about prevention and risk of syphilis, in order to improve prenatal care, once lower schooling level and history of previous treatment for syphilis was more associated and receiving information on STIs were less associated to the diagnosis of congenital syphilis at the maternity. Thus, educational health actions on STIs must be effective for timely approach and proper treatment for pregnant women with syphilis and their partners. Consequently, there will be less need for propaedeutic and treatment for children suspected of congenital syphilis.

\section{Authors' contribution}

All authors participated in the conception and study design, data acquisition or analysis/interpretation; collaborated in the preparation or revision of the submitted manuscript and approved the final version of the manuscript. 


\section{References}

1. Brasil. Ministério da Saúde. Secretária de Vigilância em Saúde. Departamento de DST, Aids e Hepatites Virais. Protocolo clínico e diretrizes terapêuticas para a prevenção da transmissão vertical de HIV, sífilis e hepatites virais. Brasília: Ministério da Saúde; 2019. Disponível em http://www.aids.gov.br/pt-br/pub/2015/protocolo-clinico-ediretrizes-terapeuticas-para-prevencao-da-transmissaovertical-de-hiv

2. Rac MW, Revell PA, Eppes CS. Syphilis during pregnancy: a preventable threat to maternal-fetal health. Am J Obstet Gynecol. 2017; 216 (4): 352-63.

3. Brasil. Ministério da Saúde. Boletim epidemiológico sífilis 2018; 48. Disponível em:http://www.aids.gov.br/ptbr/pub/2018/boletim-epidemiologico-de-sifilis-2018

4. Lago EG. Current perspectives on prevention of mother to child transmission of syphilis. Cureus. 2016; 8(3): E525. DOI: 10.7759 /cureus.525

5. Brasil. Ministério da Saúde. Portaria $N^{\circ} 77$, de 12 de Janeiro de 2012. Dispõe sobre a realização de testes rápidos, na atenção básica para a detecção de HIV e sífilis, assim como testes rápidos para outros agravos no âmbito da atenção prenatal para gestantes e suas parcerias sexuais [acesso em 26 set 2019]. Disponível em:http://bvsms.saude.gov.br/bvs/saudelegis/gm/2012/prt0 $077 \quad 1201 \quad 2012 . h t m l$

6. Brasil. Ministério da Saúde. Portaria N N 3.161, De 27 de Dezembro de 2011 Dispõe sobre a administração da penicilina nas unidades de tenção Básica à Saúde, no âmbito do Sistema Único de Saúde (SUS). [acesso em 26 set 2019] Disponível em: http://bvsms.saude.gov.br/bvs/saudelegis/ gm/2011/prt3161 $27 \quad 12$ 2011.htm

7. Brasil. Ministério da Saúde. Protocolo Clínico e Diretrizes Terapêuticas para Atenção Integral às Pessoas com Infecções Sexualmente Transmissíveis (IST). [acesso em 27 jun 2019]. Disponível em http://www.aids.gov.br/ptbr/pub/2015/protocolo-clinico-e-diretrizes-terapeuticaspara-atencao-integral-pessoas-com-infeccoes.

8. Brasil. Ministério da Saúde. Agenda de ações estratégicas para redução da sífilis no Brasil. [acesso em 26 set 2019]. Disponível em: http://www.aids.gov.br/pt-br/pub/2017/ agenda-de-acoes-estrategicas-para-reducao-da-sifilis-nobrasil

9. Brasil. Ministério da Saúde. Projeto de Resposta Rápida à Sífilis nas Redes de Atenção . [acesso em 26 set 2019]. Disponível em: <http://portalarquivos2.saude.gov.br/ images/PDF/2017/outubro/30/1.b-Projeto-Interfederativode-Resposta-Rapida-a-Sifilis-na-Rede-de-Atencao-aSaude.pdf

10. Cunha ARC, Merchan-Hamann E. Sífilis em parturientes no Brasil: prevalência e fatores associados, 2010 a 2011. Rev Panam Salud Publica. 2015; 38 (6): 479-86.

11. Rowe CR, Newberry DM, Jnah AJ. Congenital Syphilis: A Discussion of Epidemiology, Diagnosis, Management, and Nurses' Role in Early Identification and Treatment. Adv Neonatal Care 2018; 6 (12): 438-45.

12. Domingues RMSM, Leal MC. Incidência de sífilis congênita: dados do estudo nascer no Brasil. Cad Saúde
Pública. 2016; 32(6): e00082415.

13. Padovani C, Oliveira RR, Pelloso SM. Syphilis in during pregnancy: association of maternal and perinatal characteristics in a region of southern Brazil. Rev Latino-Am Enfermagem 2018; 26: e3019.

14. Lafetá KRG, Martelli Júnior H, Silveira MF, Paranaíba LMR. Sífilis materna e congênita, subnotificação e difícil controle. Rev Bras Epidemiol 2016; 19 (1): 63-74

15. Nonato SM, Melo APS, Guimarães MDC. Sífilis na gestação e fatores associados à sífilis congênita em Belo Horizonte-MG, 2010-2013. Epidemiol Serv Saúde. 2015; 24 (4): 681-94

16. Macedo VC, Lira PIC, Frias PG, Romaguera LMD, Caires SFF, Ximenes RAA. Fatores de risco para sífilis em mulheres: estudo caso-controle. Rev Saúde Pública. 2017; 51: 78

17. Newman L, Kamb M, Hawkes S, Gomez G, Say L, Seuc A, Broutet N. Global estimates of syphilis in pregnancy and associated adverse outcomes: analysis of multinational antenatal surveillance data. PLoS Med. 2013; 10(2) :e1001396

18. Coelho TTG, Medeiros ACQ, Ribeiro WCS, Menezes TB. Avaliação do grau de completude do cartão da gestante de puérperas atendidas em um hospital universitário. Rev Bras Ciênc Saúde. 2015; 12 (2): 117-22.

19. Santos Neto ET, Oliveira AE, Zandonade E, Gama SGN, Leal MC. O que os cartões de pré-natal das gestantes revelam sobre a assistência nos serviços do SUS da Região Metropolitana da Grande Vitória, Espírito Santo, Brasil? Cad Saúde Pública. 2012 ;2 8 (9): 1650-62.

20. Navega DA, Maia ACB. Conhecer e saber. Relatos de pessoas curadas da sífilis. Rev Bras Promoc Saúde. 2018; 31 (2):1-9.

21. Lima GK, Dias ICX, Araújo FM, Souza SB, Sales DS, Ferreira AGN. Educação em saúde sobre sífilis com um grupo de gestantes: um relato de experiências de acadêmicas de enfermagem. Sanare (Sobral, Online). 2013; 12 (2): 59-62

22. Lazarini FM, Barbosa DA. Educational intervention in Primary Care for the prevention of congenital syphilis. Rev. Latino-Am. Enfermagem. 2017; 25: e2845.

23. Magalhães DMS, Kawaguchi IAL, Dias A, Calderon IMP. Sífilis materna e congênita: ainda um desafio. Cad Saúde Pública. 2013; 29 (6): 1109-20.

24. Romanelli RMC, Carellos EVM, Souza HCS, Paula ATP, Rodrigues LV, Oliveira WM, Silva HHRM, Sacramento JPTC, Andrade GMQ. Management of Syphilis Pregnant Women and their Newborns: Is It Still A Problem? DST - J Bras Doenças Sex Transm. 2015; 27 35-9.

25. Silva DAR, Alves IGFG, Barros MT, Dorneles FV. Prevalência de sífilis em mulheres. Enferm Foco (Brasília). 2017; 8 (3): 61-4.

26. Oliveira DR, Figueiredo MSN. Abordagem conceitual sobre a sífilis na gestação e o tratamento de parceiros sexuais. Enferm Foco (Brasília). 2011; 2: 108-11.

27. Arnesen L, Martínez G, Mainero L, Serruya S, Durán P. 
Gestational syphilis and stillbirth in Latin America and the Caribbean. Int J Gynaecol Obstet. 2015; 128 (3): 241-5.

28. Korenromp EL, Rowley J, Alonso M, Mello MB, Wijesooriya NS, Mahiane SG, Ishikawa N, Le L, NewmanOwiredu M, Nagelkerke N, Newman L, Kamb M, Broutet N, Taylor MM. Global burden of maternal and congenital syphilis and associated adverse birthoutcomes-Estimates for 2016 and progress since 2012. PLoS ONE. 2019; 14 (2): e0211720.
29. Vasconcelos MIO, Oliveira KMC, Magalhães AHR, Guimarães RX, Linhares MSC, Queiroz MVO, Albuquerque IMN. Sífilis na gestação: estratégias e desafios dos enfermeiros da atenção básica para o tratamento simultâneo do casal. Rev Bras Promoc Saúde 2016; 29 (Supl): 85-92.

30. Duarte SJH, Almeida EP. O papel do enfermeiro do Programa Saúde da Família no atendimento Pré-Natal. Rev Enferm Cent-Oeste Min. 2014; 4.

Received on May 29, 2020

Final version presented on November 17, 2020

Approved on December 30, 2020 